\title{
Growth and yield of carrot inoculated with Bacillus subtilis and Pseudomonas fluorescens
}

\section{Crecimiento y rendimiento de zanahoria inoculada con Bacillus subtilis y Pseudomonas fluorescens}
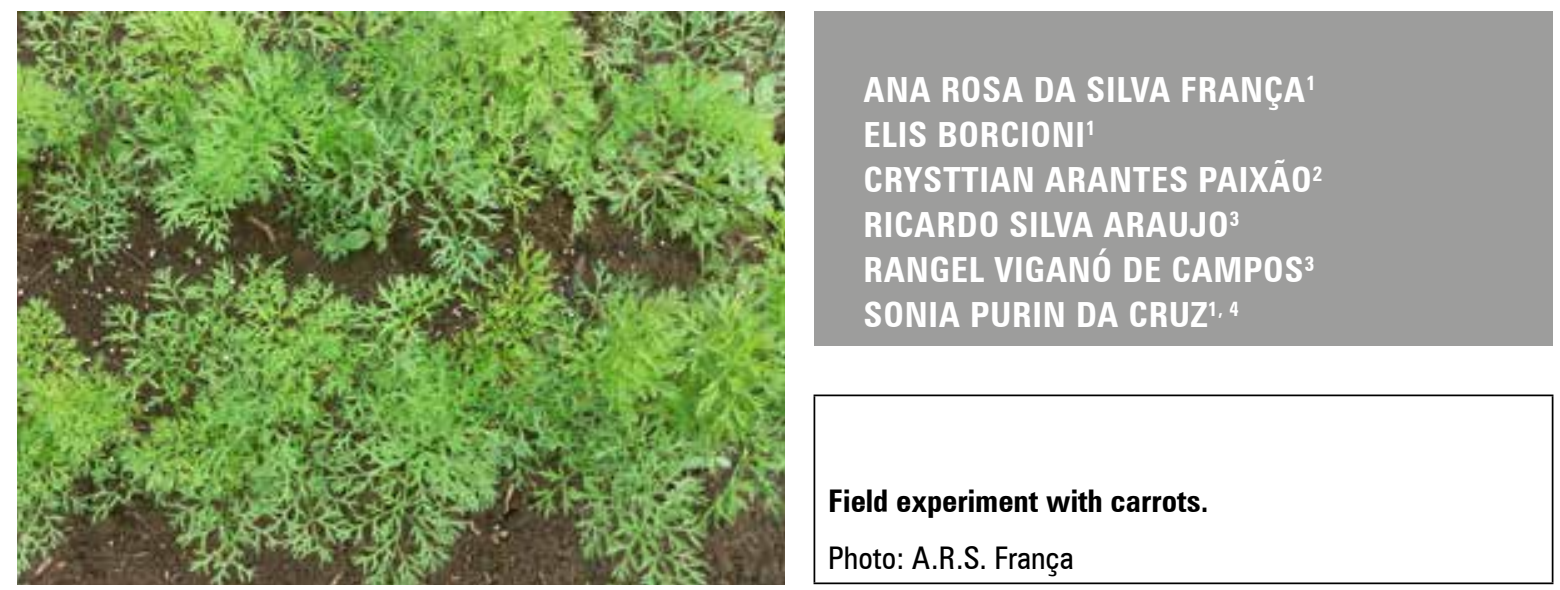

\section{ABSTRACT}

The objective of this study was to evaluate the effects of inoculation and co-inoculation with Bacillus subtilis and Pseudomonas fluorescens on carrots with reduced nitrogen use. A field experiment was carried on, with five treatments and five replicates, evaluating the growth and yield responses of inoculated carrots. Responses were observed in height only two weeks before harvesting, and the number of leaves was most affected from the beginning to the middle of the cultivation cycle. Although the fresh shoot mass was negatively affected by the inoculation treatments, the dry shoot mass did not respond to the rhizobacteria. The length of roots inoculated with $P$. fluorescens or co-inoculated with both bacteria increased from $21 \mathrm{~cm}$, without inoculation, to $25 \mathrm{~cm}$. The root volume and dry mass values were the same across the treatments. However, the fresh root mass was improved by between 70 and $81.8 \%$ with $P$. fluorescens and co-inoculation, respectively. More positive responses to inoculation were observed with reduced nitrogen levels, suggesting a potential in the rhizobacteria strains for use in reduced-input agricultural practices. Moreover, based on the findings, Pseudomonas fluorescens can be recommended as a plant growth-promoting microorganism in carrot cultivation.

Additional key words: Daucus carota; co-inoculation; plant growth promoting rhizobacteria; biofertilizers.

1 Universidade Federal de Santa Catarina, Campus Curitibanos, Centro de Ciências Rurais, Curitibanos (Brazil). ORCID França, A.R.S.: 0000-0002-3465-6396; ORCID Borcioni, E.: 0000-0001-5322-5148; ORCID Cruz, S.P.C.: 0000-0002-7805-2789

2 Universidade Federal de Santa Catarina, Campus Trindade, Florianópolis (Brazil). ORCID Paixão, C.A.: 0000-0002-3809-4490

3 Total Biotecnologia Indústria e Comércio, Curitiba (Brazil). ORCID Araújo, R.S.: 0000-0001-7348-4892; ORCID Campos, R.V.: 0000-0001-6140-2319

4 Corresponding author. s.purin@ufsc.br 


\section{RESUMEN}

El objetivo de este estudio fue evaluar los efectos de inoculación y co-inoculación de Bacillus subtilis y Pseudomonas fluorescens en plantas de zanahoria con uso reducido de nitrógeno. Se realizó un experimento de campo, con cinco tratamientos y cinco repeticiones, evaluando las respuestas de crecimiento y rendimiento de la zanahoria a la inoculación. Las respuestas sobre la altura se observaron solo dos semanas antes de la cosecha, pero el número de hojas se vio afectado principalmente desde el comienzo hasta la mitad del ciclo de cultivo. Aunque la masa de brotes frescos se vio afectada negativamente por los tratamientos de inoculación, la masa de brotes secos no respondió a las rizobacterias. La longitud de las raíces inoculadas con $P$. fluorescens o co-inoculadas con ambas bacterias aumentó de $21 \mathrm{~cm}$, sin inoculación, a $25 \mathrm{~cm}$. Los valores del volumen de la raíz y la masa seca fueron los mismos en todos los tratamientos. Sin embargo, la masa de raíces frescas mejoró entre 70 y $81.8 \%$ por $P$. fluorescens y co-inoculación, respectivamente. La mayoría de las respuestas positivas a la inoculación se observaron con niveles reducidos de nitrógeno, lo que sugiere el potencial de estas cepas de rizobacterias para ser utilizadas en prácticas agrícolas de insumos reducidos. Además, nuestros hallazgos respaldan la recomendación de Pseudomonas fluorescens como microorganismo promotor del crecimiento de las plantas utilizado para el cultivo de zanahorias.

Palabras clave adicionales: Daucus carota; coinoculación; rizobacterias promotoras del crecimiento de las plantas; biofertilizantes.

Received for publication: 20-03-2020 Accepted for publication: 23-11-2020



Carrot (Daucus carota L.) is an important crop, grown and consumed in most countries worldwide. China and the United States are the top producers. In Brazil, the carrot is the fifth most cultivated crop, and its average yield ranges from 30 to $35 \mathrm{t} \mathrm{ha}^{-1}$ (Paula, 2019).

Carrot yield and quality rely on many factors related to soil fertility and irrigation. Inadequate growth conditions result in physiological anomalies and reduced root mass, which decrease market value or even cause product losses of up to $30 \%$ (Nick and Borém, 2016). Inoculation with plant growth-promoting rhizobacteria (PGPR) is a promising alternative that improves environmental conditions for carrot crops, as previously reported for other agricultural species. The benefits of PGPR in other crops include higher germination rates, increased root and shoot biomass, improved nutrition and resistance to biotic and abiotic stresses (Kloepper et al., 1980; Vessey, 2003; Aloo et al., 2019; Fioreze et al., 2020; Lin et al., 2020).

Studies on inoculation benefits in carrots are scarce and focus on a small number of measured parameters. Evaluations by Kozusny-Andreani et al. (2014), Matsuoka et al. (2016) and Clemente et al. (2016) reported the benefits of Pseudomonas and Bacillus as increased root length, fresh mass and dry root mass.
Different PGPR species can be combined in a process known as co-inoculation. The benefits of co-inoculation are well reported for several crops, such as soybean, common bean and corn (Molla et al., 2001; Fukami et al., 2018; Kumawat et al., 2019; Zeffa et al., 2020). The inoculation of soybean with Bradyrhizobium japonicum resulted in a yield of $2,200 \mathrm{~kg} \mathrm{ha}^{-1}$, while co-inoculation with this bacterium and Azospirillum brasilense increased this value by $12 \%\left(2,496 \mathrm{~kg} \mathrm{ha}^{-1}\right)$. Common bean yield also benefited from co-inoculation, with production of $1,866 \mathrm{~kg} / \mathrm{ha}$ when Rhizobium tropici was used with Azospirillum brasilense, as compared to inoculation with only Rhizobium tropici, which resulted in $1,543 \mathrm{~kg} \mathrm{ha}^{-1}$ (Hungria et al., 2013).

Only one study by Merriman et al. (1974) has provided information on the benefits of co-inoculation in carrots. These authors described the benefits of $\mathrm{Ba}$ cillus subtilis and Streptomyces griseus, which included $17 \%$ more root mass than without inoculation. However, all studies on carrots either lack bacterial species designation or do not include evaluations during the entire crop cycle, which limits the understanding of inoculation and co-inoculation benefits. Moreover, the use of PGPR with reduced $\mathrm{N}$ levels has not been evaluated in any published study but this practice warrants research considering global dependence on nitrogen fertilizers. The benefits of rhizobacteria in 
crops such as corn and soybean are often expressed or optimized with reduced nitrogen fertilization, which decreases the costs of crop production (Mendes et al., 2003; Lana et al., 2012). Therefore, this study tested the hypothesis that inoculation with two PGPR ( $B a-$ cillus subtilis and Pseudomonas fluorescens) with reduced nitrogen levels improves growth and yield in carrots.

\section{MATERIALS AND METHODS}

This experiment was established in Ponte Alta do Norte, Santa Catarina State, Brazil (2713'29' S and $50^{\circ} 25^{\prime} 28^{\prime} \mathrm{W}$ ) at $990 \mathrm{~m}$ a.s.l. The climate was classified as Cfb (Köppen's classification) with average temperatures between 12.4 and $22.0^{\circ} \mathrm{C}$. Prior to establishing the experiment, soybean and corn were cultivated in the area for several years.

Soil samples $(0-20 \mathrm{~cm})$ were collected to analyze chemical properties and soil granulometry. The results were: $\mathrm{pH}$ in $\mathrm{H}_{2} \mathrm{O}$ 6.60; $\mathrm{Ca} 9.65 \mathrm{cmol}_{c} \mathrm{dm}^{-3} ; \mathrm{Mg}$ $5.35 \mathrm{cmol}_{\mathrm{c}} \mathrm{dm}^{-3} ; \mathrm{H}+\mathrm{Al} 2.00 \mathrm{cmol}_{\mathrm{c}} \mathrm{dm}^{-3} ; \mathrm{K} 0.15 \mathrm{cmol}_{\mathrm{c}}$ $\mathrm{dm}^{-3}$; P $6.00 \mathrm{mg} \mathrm{dm}^{-3}$, Na $1.00 \mathrm{mg} \mathrm{dm}^{-3}$ and $\mathrm{K} 1.57 \mathrm{mg}$ $\mathrm{dm}^{-3}$. The CTC at pH 7.0 was $13.99 \mathrm{cmol}_{\mathrm{c}} \mathrm{dm}^{-3}$, the effective CTC was $19.59 \mathrm{cmol}_{c} \mathrm{dm}^{-3}$, the saturation of bases was $90.74 \%$, the organic matter content was $3.30 \%$, the soil $\mathrm{C}$ content was $1.91 \% \mathrm{C}$, and the clay was $39 \%$.

Correction of the soil $\mathrm{pH}$ was not necessary because the value was within the range of requirements for this crop. Fertilization was done with N, P and K as recommended for carrot crops in Brazil. A $\mathrm{N}$ dose of $20 \mathrm{~kg} \mathrm{ha}^{-1}$ (as urea) was applied in the furrows before sowing in the control treatment $(100 \% \mathrm{~N})$. This value was reduced to $20 \%$ in all other inoculation treatments. $80 \mathrm{~kg}$ of N/ha were split-applied at 15, 30 and 40 days after sowing-DAS (16, 24 and $40 \mathrm{~kg}$ ) in all treatments as recommended for this crop in southern Brazil (COFS, 2016). Fertilization with $\mathrm{P}$ and $\mathrm{K}$ (as $\mathrm{P}_{2} \mathrm{O}_{5}$ and $\mathrm{K}_{2} \mathrm{O}$ ) was performed in all experiment units. $240 \mathrm{~kg} \mathrm{ha}^{-1}$ of $\mathrm{P}_{2} \mathrm{O}_{5}$ were applied only at sowing, and $190 \mathrm{~kg} / \mathrm{ha}$ of $\mathrm{K}_{2} \mathrm{O}$ were split-applied at 15 , 30 and $40 \mathrm{DAS}$ (38, 57 and $95 \mathrm{~kg}$, respectively).

The carrots were cultivated between 2018 and 2019 in the summer seasons. Seeds of the Livia cultivar (Brasilia group) were used, with 90-100 d required for complete development. The distance between rows was $20 \mathrm{~cm}$, while the distance between seeds was $8 \mathrm{~cm}$. The experiment used completely randomized design with five treatments and five replicates. Each experimental plot was $1 \mathrm{~m}^{2}$ and was spaced $0.2 \mathrm{~m}$ from the other plots.

Five treatments were tested: $100 \% \mathrm{~N} ; 20 \% \mathrm{~N} ; 20 \%$ $\mathrm{N}$ and inoculation with Bacillus subtilis $(20 \% \mathrm{~N}+B$. subtilis); $20 \% \mathrm{~N}$ and inoculation with Pseudomonas fluorescens (20\% N+P. fluorescens); $20 \% \mathrm{~N}$ and coinoculation with B. subtilis and P. fluorescens $(20 \%$ $\mathrm{N}+\mathrm{co}$-inoculation). All inoculants were provided by Total Biotecnologia (Curitiba, Brazil) and developed in liquid form. Both inoculants had a concentration of $1.0 \cdot 10^{8} \mathrm{CFU} / \mathrm{mL}$ (commercial registration for soybean and maize at Ministry of Agriculture, Livestock, and Supply - MAPA, B. subtilis: PR 9392310112-8; P. fluorescens: PR 9392310104-7;). However, there were no recommendations for these inoculants in carrots.

In the $20 \% \mathrm{~N}+B$. subtilis and $20 \% \mathrm{~N}+$ P. fluorescens treatments, inoculants were applied in the rows at sowing. The inoculants were diluted in water (1L:499L per hectare), and this mixture was sprayedapplied inside the rows before sowing. In the 20\% $\mathrm{N}+\mathrm{co}$-inoculation treatment, the ratio was adjusted to $1 \mathrm{~L}$ of each inoculant, diluted in $498 \mathrm{~L}$ of water. Inoculants were also applied in the rows at sowing.

After emergence, weed thinning and controls were performed manually throughout the entire experiment, as recommended by Vieira and Pessoa (2008), and no chemical product was used at any stage.

Several parameters were evaluated throughout plant growth and at harvest, as recommended for carrots by CEAGESP (2000). The plant height and number of green leaves were evaluated at $38,45,52,66,80$, 95 and 100 DAS.

At harvest, the roots and shoots were separated, and the fresh mass of both components was immediately determined. The root length was measured with a ruler. The root volume was estimated by placing the carrots in a flask with water and measuring the volume of liquid displaced (Novoselov, 1960). The plant material was dried in an air-forced dryer at $65^{\circ} \mathrm{C}$ until constant weight, and the mass of the dry roots and shoots was determined.

The presence of defects in each root was evaluated (split roots, cracks, purple shoulder, green shoulder and adventitious roots), which was used to calculate the percentage of abnormal roots. 
Tests of normality and homogeneity of variances were applied to all data. If the assumptions of ANO$V A$ were fulfilled, then the $\mathrm{F}$ test was used. When a significant $\mathrm{p}$ value was obtained $(P \leq 0.05)$, the means were separated with the Scott-Knott test using the $\mathrm{R}$ Core Team program (2020). The data on root defects did not satisfy any statistical conditions of the ANOVA or non-parametric procedures, even when submitted to several forms of transformation. Therefore, only mean and average values were recorded.

\section{RESULTS AND DISCUSSION}

The plant height increased in all inoculation treatments, as compared to $100 \% \mathrm{~N}$ and $20 \% \mathrm{~N}$ from $95 \mathrm{DAS}$ on. The average increase in growth ranged from five to eleven centimeters (Tab. 1). The highest values were observed when the carrots were co-inoculated with B. subtilis and $P$. fluorescens $(73.22 \mathrm{~cm})$, as compared to nitrogen dose $(62.26 \mathrm{~cm})$.
Effects of inoculation on the number of green leaves were observed only until 66 DAS (Tab. 2). Inoculation with $P$. fluorescens was the only treatment that promoted the same number of leaves as 100\% nitrogen across all evalutions where statistical differences were observed, namely up to 66 DAS (Tab. 2).

The highest mean fresh shoot mass was detected with $100 \% \mathrm{~N}$ and use of nitrogen, and all inoculation treatments with reduced nitrogen levels decreased shoot biomass production (Tab. 3). On the other hand, root length was increased by inoculation with $P$. fluorescens and co-inoculation, as compared to $100 \% \mathrm{~N}, 20 \% \mathrm{~N}$ and $20 \% \mathrm{~N}+$ B. subtilis. The plants inoculated with both bacteria produced roots that were, on average, four to five centimeters longer than in the plants that were inoculated only with $B$. subtilis or not inoculated, regardless of the $\mathrm{N}$ supply (Tab. 3).

The fresh root mass increased when the plants were inoculated with $P$. fluorescens and co-inoculated with $P$.

Table 1. Height of carrot plants $(\mathrm{cm})$ from 38 to 100 days after sowing (DAS), grown under different inoculation treatments. Ponte Alta do Norte-SC, Brazil.

\begin{tabular}{|l|c|c|c|c|c|c|c|}
\hline \multicolumn{1}{|c|}{ Treatment } & 38 DAS & 45 DAS & 52 DAS & 66 DAS & 80 DAS & 95 DAS & 100 DAS \\
\hline $100 \% \mathrm{~N}$ & 9.78 & 13.04 & 21.82 & 43.74 & 51.08 & $58.34 \mathrm{~b}$ & $62.26 \mathrm{~b}$ \\
\hline $20 \% \mathrm{~N}$ & 9.36 & 12.88 & 22.98 & 42.86 & 50.90 & $61.36 \mathrm{~b}$ & $65.10 \mathrm{~b}$ \\
\hline $20 \% \mathrm{~N}+$ B. subtilis & 7.86 & 11.34 & 21.30 & 42.34 & 51.90 & $66.46 \mathrm{a}$ & $69.02 \mathrm{a}$ \\
\hline $20 \% \mathrm{~N}+$ P. fluorescens & 7.48 & 10.42 & 20.44 & 43.82 & 53.40 & $65.58 \mathrm{a}$ & $68.74 \mathrm{a}$ \\
\hline $20 \% \mathrm{~N}+$ co-inoculation & 6.26 & 9.16 & 20.62 & 41.50 & 51.92 & $67.42 \mathrm{a}$ & $73.22 \mathrm{a}$ \\
\hline CV (\%) & 25.29 & 23.40 & 9.24 & 7.19 & 6.06 & 6.04 & 5.85 \\
\hline $\mathrm{Pr}>\mathrm{Fc}$ & 0.0910 & 0.1566 & 0.2981 & 0.7348 & 0.7400 & 0.0085 & 0.0053 \\
\hline
\end{tabular}

Means with different letters indicate significant differences according to the Scott-Knott test $(P<0.05)$. CV: Coefficient of variation; $20 \% \mathrm{~N}+\mathrm{co}$-inoculation: $B$. subtilis and $P$. fluorescens.

Table 2. Green leaves in carrot plants from 38 to 100 days after sowing (DAS), grown under different inoculation treatments. Ponte Alta do Norte-SC, Brazil.

\begin{tabular}{|l|c|c|c|c|c|c|c|}
\hline \multicolumn{1}{|c|}{ Treatment } & 38 DAS & 45 DAS & 52 DAS & 66 DAS & 80 DAS & 95 DAS & 100 DAS \\
\hline $100 \% \mathrm{~N}$ & $4.84 \mathrm{a}$ & $6.48 \mathrm{a}$ & $8.22 \mathrm{a}$ & $9.20 \mathrm{a}$ & 10.74 & 12.60 & 13.16 \\
\hline $20 \% \mathrm{~N}$ & $4.48 \mathrm{a}$ & $5.88 \mathrm{~b}$ & $7.46 \mathrm{~b}$ & $8.48 \mathrm{~b}$ & 9.78 & 10.24 & 11.06 \\
\hline $20 \% \mathrm{~N}+$ B. subtilis & $3.72 \mathrm{~b}$ & $5.64 \mathrm{~b}$ & $8.20 \mathrm{a}$ & $8.82 \mathrm{~b}$ & 10.62 & 11.52 & 13.08 \\
\hline $20 \% \mathrm{~N}+$ P. fluorescens & $4.48 \mathrm{a}$ & $6.68 \mathrm{a}$ & $8.64 \mathrm{a}$ & $9.40 \mathrm{a}$ & 10.54 & 10.32 & 11.64 \\
\hline $20 \% \mathrm{~N}+\mathrm{co}$-inoculation & $4.60 \mathrm{a}$ & $5.72 \mathrm{~b}$ & $7.98 \mathrm{ab}$ & $9.06 \mathrm{a}$ & 10.32 & 11.40 & 12.34 \\
\hline $\mathrm{CV}(\%)$ & 11.13 & 7.99 & 6.57 & 4.67 & 11.94 & 15.50 & 18.85 \\
\hline $\mathrm{Pr}>\mathrm{FC}$ & 0.0272 & 0.0108 & 0.0387 & 0.0287 & 0.7602 & 0.2300 & 0.5567 \\
\hline
\end{tabular}

Means with different letters indicate significant differences according to the Scott-Knott test $(P<0.05)$. CV: Coefficient of variation; $20 \% \mathrm{~N}+$ co-inoculation: $B$. subtilis and $P$. fluorescens. 
Table 3. Fresh and dry shoot mass, root length and volume, and fresh and dry root mass in carrot plants grown under different inoculation treatments. Ponte Alta do Norte-SC, Brazil.

\begin{tabular}{|l|c|c|c|c|c|c|}
\hline \multicolumn{1}{|c|}{ Treatment } & $\begin{array}{c}\text { Mass of fresh shoot } \\
(\mathrm{g})\end{array}$ & $\begin{array}{c}\text { Mass of dry shoot } \\
(\mathrm{g})\end{array}$ & $\begin{array}{c}\text { Root length } \\
(\mathrm{cm})\end{array}$ & $\begin{array}{c}\text { Root volume } \\
(\mathrm{mL})\end{array}$ & $\begin{array}{c}\text { Mass of fresh } \\
\text { roots }(\mathrm{g})\end{array}$ & $\begin{array}{c}\text { Mass of dry roots } \\
(\mathrm{g})\end{array}$ \\
\hline $100 \% \mathrm{~N}$ & $177.04 \mathrm{a}$ & 18.98 & $21.24 \mathrm{~b}$ & 296.80 & $164.97 \mathrm{~b}$ & 16.72 \\
\hline $20 \% \mathrm{~N}$ & $135.54 \mathrm{~b}$ & 15.78 & $21.30 \mathrm{~b}$ & 302.56 & $172.62 \mathrm{~b}$ & 16.79 \\
\hline $20 \% \mathrm{~N}+$ B. subtilis & $81.54 \mathrm{c}$ & 11.98 & $19.78 \mathrm{~b}$ & 202.40 & $194.02 \mathrm{~b}$ & 19.60 \\
\hline $20 \% \mathrm{~N}+$ P. fluorescens & $67.18 \mathrm{c}$ & 12.76 & $25.08 \mathrm{a}$ & 216.80 & $281.05 \mathrm{a}$ & 21.48 \\
\hline $20 \% \mathrm{~N}+$ co-inoculation & $66.66 \mathrm{c}$ & 12.44 & $25.30 \mathrm{a}$ & 217.60 & $300.38 \mathrm{a}$ & 23.17 \\
\hline CV (\%) & 27.14 & 34.17 & 10.94 & 29.70 & 29.21 & 31.28 \\
\hline Pr>FC & 0.0001 & 0.1735 & 0.0075 & 0.1199 & 0.0100 & 0.3975 \\
\hline
\end{tabular}

Means with different letters indicate significant differences according to the Scott-Knott test $(P<0.05)$. CV: Coefficient of variation; $20 \% \mathrm{~N}+$ co-inoculation: $B$. subtilis and $P$. fluorescens.

fluorescens and B. subtilis (Tab. 3). Compared to $100 \%$ $\mathrm{N}$, co-inoculation promoted an increase of $81.8 \%$ in the root mass, whereas inoculation with only $P$. fluorescens improved the fresh root mass by $70 \%$.

More than $50 \%$ of the roots were considered normal (Tab. 4). The only treatment in which split roots were not observed was $20 \% \mathrm{~N}+\mathrm{co}$-inoculation. Purple and green shoulders were detected in all treatments except $100 \% \mathrm{~N}$ (Tab. 4).

This is the first study evaluating the effects of inoculation in carrots on developmental parameters throughout the crop entire cycle. This is also the first report on co-inoculation benefits for growth and yield in carrots. These findings contribute to more sustainable agricultural practices linked to economical gains and broadens the range of crop species known to benefit from co-inoculation.

There are no previous records on plant height measurements throughout the entire development cycle in response to inoculation in carrots. Our data suggest that the effects of bacteria on this variable are detected towards the physiological maturity of carrots. The opposite pattern was observed for the number of green leaves. No effects of any treatment were observed after 80 DAS. P. fluorescens was the most efficient bacterium for increasing the number of leaves. Reports on other plant species collaborate the beneficial effects of Pseudomonas on this parameter. Corrêa et al. (2010), for example, analyzed the response of lettuce to Pseudomonas chlororaphis and observed 4 to $7 \%$ more leaves as a result of inoculation.

All inoculation treatments had smaller shoot mass values. Other studies, however, have shown no significant differences with inoculation. Matsuoka et al. (2016) inoculated carrots with ACC (1-aminocyclopropane-1-carboxylate) deaminase-producing bacteria isolated from carrots, turnips and sweet peppers (called OFT2, OFT5, and RH7). They observed no effect from inoculation on the fresh leaf mass, with values ranging from 20 to 24 g per plant. KozusnyAndreani et al. (2014) tested the effects of 14 unidentified rhizobacteria isolated from Crotalaria spectabilis

Table 4. Percentages of normal, split and cracked roots, occurrence of purple and green shoulders, adventitious roots and other deffects in carrot plants grown under different inoculation treatments. Ponte Alta do Norte-SC, Brazil.

\begin{tabular}{|l|c|c|c|c|c|c|c|}
\hline \multicolumn{1}{|c|}{ Treatment } & $\begin{array}{c}\text { Normal } \\
\text { roots }\end{array}$ & $\begin{array}{c}\text { Split } \\
\text { roots }\end{array}$ & $\begin{array}{c}\text { Cracked } \\
\text { roots }\end{array}$ & $\begin{array}{c}\text { Purple } \\
\text { shoulder }\end{array}$ & $\begin{array}{c}\text { Green } \\
\text { shoulder }\end{array}$ & $\begin{array}{c}\text { Adventitious } \\
\text { roots }\end{array}$ & Other deffects \\
\hline $100 \% \mathrm{~N}$ & 56.57 & 16.67 & 13.33 & 0.00 & 0.00 & 3.33 & 10.1 \\
\hline $20 \% \mathrm{~N}$ & 56.67 & 16.67 & 6.66 & 16.67 & 3.33 & 0.00 & 0.00 \\
\hline $20 \% \mathrm{~N}+$ B. subtilis & 56.67 & 13.33 & 10.00 & 6.67 & 10.00 & 0.00 & 3.33 \\
\hline $20 \% \mathrm{~N}+$ P. fluorescens & 53.33 & 6.67 & 13.33 & 20.00 & 3.33 & 3.33 & 0.01 \\
\hline $20 \% \mathrm{~N}+$ co-inoculation & 76.68 & 0.00 & 6.66 & 13.33 & 3.33 & 0.00 & 0.00 \\
\hline CV (\%) & 40.19 & 117.44 & 120.07 & 207.19 & 214.48 & 364.43 & 276.39 \\
\hline
\end{tabular}

CV: Coefficient of variation; $20 \% \mathrm{~N}+$ co-inoculation: $B$. subtilis and $P$. fluorescens. 
on carrots and found no difference between the control and inoculation treatments for shoot mass.

Increases in root length in response to inoculation with PGPR have been reported by other researchers. Kozusny-Andreani et al. (2014) observed a large variation in root length between different isolates (14 - 22 $\mathrm{cm}$ ) in different treatments, with ten out of 14 bacterial isolates increasing root length as compared to no inoculation. Positive responses in root length are important in carrots because this trait is commercially valuable. Five commercial classes were established in Brazil according to Nick and Borém (2016): 10 (>10 and $<14 \mathrm{~cm}), 14(>14$ and $<18 \mathrm{~cm}), 18(>18$ and $<22$ $\mathrm{cm}), 22(>22$ and $<26 \mathrm{~cm})$ and $26(>26 \mathrm{~cm})$. Treatments 1,2 and 3 resulted in values belonging to Class 18. However, only the treatments with inoculation with $P$. fluorescens and co-inoculation with $P$. fluorescens and $B$. subtilis resulted in longer roots, with values belonging to class 22 . Therefore, inoculation with these two bacteria may be an alternative for improving the commercial quality of carrots grown with a decreased $\mathrm{N}$ supply.

Yield was improved by inoculation with $P$. fluorescens and co-inoculation with $P$. fluorescens and $B$. subtilis. Merriman et al. (1974) first reported the benefits of Bacillus subtilis associated with Streptomyces griseus in carrots, increasing root mass by $17 \%$. KozusnyAndreani et al. (2014) tested 14 bacterial strains, and half of them were effective at promoting the fresh root biomass. These authors showed that, while the treatment with only $\mathrm{N}$ resulted in $28 \mathrm{~g}$ of roots, inoculation with the strain UCCBj-CE1 resulted in more than $60 \mathrm{~g}$ of roots. Clemente et al. (2016) studied the response of carrots to Bacillus subtilis and B. methylotrophicus and observed increased fresh root mass in carrots. Without inoculation, the mean value was $5.9 \mathrm{~kg} \mathrm{~m}^{-2}$. Inoculation with $B$. subtilis increased the fresh root mass $\left(6.5 \mathrm{~kg} \mathrm{~m}^{-2}\right)$, as well as inoculation with $B$. methylotrophicus $\left(7.26 \mathrm{~kg} \mathrm{~m}^{2}\right)$. On the other hand, Matsuoka et al. (2016) found no differences in the mass of fresh roots inoculated with two bacterial strains. One of them (RH7) actually reduced the root mass to $37 \mathrm{~g}$, as compared to 48.7 $\mathrm{g}$ in the control. Phylogenetic analyses revealed that all strains are related to species that belong to the genus Pseudomonas.

There was no difference between the treatments for dry root mass. However, Kozusny-Andreani et al.
(2014) quantified more dry roots in carrots inoculated with four strains of unidentified rhizobacteria (mean of $5.5 \mathrm{~g}$ ) and compared them to a nitrogen control (3 g).

The statistical analysis of data on carrot problems (such as split root, cracked roots, purple shoulders, green shoulders or adventitious roots) was not possible. However, co-inoculation was the only condition in which no plants presented split roots. Both biotic and abiotic stresses are known to cause split and cracked roots, often associated with inadequate humidity. Rhizobacteria are known to produce exopolysaccharides that help retain water in the rhizosphere and reduce physical damage in roots (Chang et al., 2007). Rhizobacteria may decrease the occurrence of purple and green shoulders; however, an analysis of the data related to this hypothesis was not possible. According to Patten and Glick (1996), rhizobacteria are known to produce indole acetic acid, which promotes root elongation and deeper penetration in soils, resulting in less exposure to the soil surface and sunlight. Further studies should be carried out to better understand the effects of inoculation on reducing carrot defects.

The hypothesis was not confirmed because not all inoculation treatments with reduced $\mathrm{N}$ levels were effective in promoting plant development. The benefits of $B$. subtilis were also less pronounced than those of P. fluorescens. Although co-inoculation was as efficient as inoculation with only $P$. fluorescens, both treatments were outstanding methods for increasing growth and yield in carrots. Reduced $\mathrm{N}$ fertilization to obtain carrots that are classified in commercial classes with a higher aggregate value may motivate farmers to incorporate inoculation as a routine practice when growing carrots.

\section{CONCLUSION}

Bacillus subtilis and Pseudomonas fluorescens improve growth and yield in carrots and are plant growthpromoting microorganisms used with reduced levels of nitrogen fertilization.

Conflict of interests: The manuscript was prepared and reviewed with the participation of the authors, who declare that there exists no conflict of interest that puts at risk the validity of the presented results. 


\section{BIBLIOGRAPHIC REFERENCES}

Aloo, B.N., B.A. Makumba, and E.R. Mbega. 2019. The potential of Bacilli rhizobacteria for sustainable crop production and environmental sustainability. Microbiol. Res. 219, 26-39. Doi: 10.1016/j.micres.2018.10.011

CEAGESP, Companhia de Entrepostos e Armazéns Gerais de São Paulo. 2000. Normas de classificação da cenoura. COH/CEAGESP, São Paulo, Brazil.

Chang, W.S., M. Van de Mortel, L. Nielsen, G.N. Guzman, X. Li, and L.J. Halverson. 2007. Alginate production by Pseudomonas putida creates a hydrated 133 microenvironment and contributes to biofilm architecture and stress tolerance under water-limiting conditions. J. Bacteriol. 189(22), 8290-8290. Doi: 10.1128/JB.00727-07

Clemente, J.M., C.R. Cardoso, B.S. Vieira, I.M. Flor, and R.L. Costa. 2016. Use of Bacillus spp. as growth promoter in carrot crop. Afr. J. Agric. Res. 11(35), 33553359. Doi: 10.5897/AJAR2016.11316

Corrêa, E.B., W. Bettiol, and J.C. Sutton. 2010. Controle biológico da podridão radicular (Pythium aphanidermatum) e promoção de crescimento por Pseudomonas chlororaphis 63-28 e Bacillus subtilis GB03 em alface hidropônica. Summa Phytopathol. 36(4), 275-281. Doi: 10.1590/S0100-54052010000400001

CQFS, Comissão de Química e Fertilidade do Solo. 2016. Manual de adubação e de calagem para os Estados do Rio Grande do Sul e de Santa Catarina. Sociedade Brasileira de Ciência do Solo, Porto Alegre, Brazil.

Fioreze, S.L., M.G. Pinheiro, Y.D. Pereira, and S.P. Cruz. 2020. Inoculation of wheat plants with Pseudomonas spp. and Azospirillum brasilense under drought stress. J. Exp. Agric 42(2), 1-7. Doi: 10.9734/jeai/2020/ v42i230461

Fukami, J., C. de la Osa, F. Javier Ollero, M. Megías, and M. Hungria. 2018. Co-inoculation of maize with Azospirillum brasilense and Rhizobium tropici as a strategy to mitigate salinity stress. Funct. Plant Biol. 45, 328-339. Doi: 10.1071/FP17167

Hungria, M., M.A. Nogueira, and R.S. Araujo. 2013. Co-inoculation of soybeans and common beans with rhizobia and azospirilla: strategies to improve sustainability. Biol. Fertil. Soils 49(7), 791-801. Doi: 10.1007/ s00374-012-0771-5

Kloepper, J.W., J. Leong, M. Teintze, and M.N. Schroth. 1980. Enhanced plant-growth by siderophores produced by plant growth-promoting rhizobacteria. Nature 286, 885-886. Doi: 10.1038/286885a0

Kozusny-Andreani, D.I., J.C. Agiado, and R. Andreani Junior. 2014. Efeito de bactérias rizosféricas sobre o desenvolvimento da cenoura. Rev. Univ. Vale Rio Verde 12, 211-220. Doi: 10.5892/ruvrd.v12i1.1368
Kumawat, K.C., P. Sharma, A. Sirari, I. Singh, B.S. Gill, U. Singh, and K. Saharan. 2019. Synergism of Pseudomonas aeruginosa (LSE-2) nodule endophyte with Bradyrhizobium sp. (LSBR-3) for improving plant growth, nutrient acquisition and soil health in soybean. World J. Microbiol. Biotechnol. 35, 47. Doi: 10.1007/ s11274-019-2622-0

Lana, M.C., J. Dartora, D. Marini, and J.E. Hann. 2012. Inoculation with Azospirillum, associated with nitrogen fertilization in maize. Rev Ceres 59(3), 399-405. Doi: 10.1590/S0034-737X2012000300016

Lin, Y., D.B. Watts, J.W. Kloepper, Y. Feng, and H.A. Torbert. 2020. Influence of plant growth-promoting rhizobacteria on corn growth under drought stress. Commun Soil Sci. Plant Anal. 51(2), 250-264. Doi: 10.1080/00103624.2019.1705329

Matsuoka, H., Y. Ohwaki, J. Terakado-Tonooka, and F. Tanaka. 2016. Changes in volatiles in carrots inoculated with ACC deaminase-producing bacteria isolated from organic crops. Plant Soil 407, 173-186. Doi: 10.1007/s11104-015-2769-x

Mendes, I.C., M. Hungria, and M.A.T. Vargas. 2003. Soybean response to starter nitrogen and Bradyrhizobium inoculation on a cerrado oxisol under no-tillage and conventional tillage systems. R. Bras. Ci. Solo 27(1), 81-87. Doi: 10.1590/S0100-06832003000100009

Merriman, P.R., R.D. Price, J.F. Kollmorgen, T. Piggott, and E.H. Ridge. 1974. Effect of seed inoculation with $\mathrm{Ba}$ cillus subtilis and Streptomyces griseus on the growth of cereals and carrots. Aust. J. Agric Res. 25(2), 219-226. Doi: 10.1071/AR9740219

Molla, A.H., Z.H. Shamsuddin, M.S. Halimi, M. Morziah, and A.B. Puteh. 2001. Potential for enhancement of root growth and nodulation of soybean coinoculated with Azospirillum and Bradyrhizobium in laboratory systems. Soil Biol. Biochem. 33(4), 457-463. Doi: 10.1016/S0038-0717(00)00186-3

Nick, C. and A. Borém. 2016. Cenoura do plantio à colheita. Editora UFV, Viçosa, Brazil.

Novoselov, V.S. 1960. A closed volumeter for plant root systems. Fiziologiya Rastenii 7, 243-244.

Patten, C.L. and B.R. Glick. 1996. Bacterial biosynthesis of indole-3-acetic acid. Can. J. Microbiol. 42(3), 207-220. Doi: $10.1139 / \mathrm{m} 96-032$

Paula, L.B. 2019. Cenoura: área menor, produtividade maior. Campo \& Negócio, Piracicaba, Brazil.

R Core Team. 2020. R: A language and environment for statistical computing. R Foundation for Statistical Computing, Vienna.

Vessey, J.K. 2003. Plant growth promoting rhizobacteria as biofertilizers. Plant Soil 255(2), 571-586. Doi: 10.1023/A:1026037216893 
Vieira, J.V. and H.B.S.V. Pessoa. 2008. Cenoura (Daucus carota): Clima. Embrapa Hortaliças, Brasilia, DF.

Zeffa, D.M., L.H. Fantin, A. Koltun, A.L.M. de Oliveira, M.P.B.A. Nunes, M.G. Canteri, and L.S.A. Goncalves.
2020. Effects of plant growth-promoting rhizobacteria on co-inoculation with Bradyrhizobium in soybean crop: a meta-analysis of studies from 1987 to 2018. Peer J. 8, e7905. Doi: 10.7717/peerj.7905 